This article is distributed under the terms of the Creative Commons Attribution 3.0 PL (c) Copyright by Uniwersytet Warszawski Katedra Studiów Interkulturowych Europy Środkowo-Wschodniej \& individual articles to their Authors

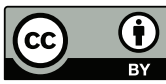

doi: 10.32612/uw.2543618X.2020.pp.363-375

Przegląd Środkowo-Wschodni, 5, 2020

ISSN 2543-618X elSSN 2545-1324

Nr art. 20200511

Data przesłania: 22.11 .2019

Data akceptacji: 12.12.2019

\section{Justyna Szlachta-Ignatowicz}

Uniwersytet Warszawski j.szlachta-ignatowicz@uw.edu.pl

ORCID: 0000-0002-8889-1535

\title{
Muzeum ziemi ojczystej (Heimatmuseum) Siegfrieda Lenza jako opowieść o próbie ocalenia
}

Zagadnienia dotyczące tożsamości można rozpatrywać z wielu perspektyw. Jednym ze sposobów jest próba opisania kultury niewielkiej społeczności, która w wyniku zawirowań historycznych powoli zanika. Taką tematykę porusza Siegfried Lenz w książce Muzeum ziemi ojczystej, która stanowi przedmiot analizy w artykule. Pisarz dotyka problemów związanych z zanikającą kulturą mazurską. Chce pokazać, w jaki sposób można próbować ją ochronić wraz z tożsamością jej przedstawicieli, ale również wskazać, jak szybko można doprowadzić do kompletnego jej zaniku.

Słowa kluczowe: tożsamość, ogień, Mazury, muzeum, pogranicze, pamięć

Zagadnienia dotyczące tożsamości można rozpatrywać $\mathrm{z}$ wielu perspektyw. Można analizować jej problemy, zważywszy na przedstawiciela i tym samym wyróżnić tożsamość jednostkową ${ }^{1}$ i zbiorową; można się zastanawiać, czy tożsamość jest stanem czy raczej procesem; można również spróbować opisać kulturę niewielkiej społeczności, która w wyniku zawirowań historycznych powoli zanika ${ }^{3}$. Każda próba

${ }^{1}$ Zob. B. Skarga, Tożsamość i różnica. Eseje metafizyczne, Znak, Kraków 1997.

${ }^{2}$ Zob. Z. Bokszański, Tożsamości zbiorowe, WN PWN, Warszawa 2015.

${ }^{3}$ Niektórzy twierdzą, że kultury regionalne, szczególnie w Polsce, już zanikły. A pozostałości, jakie można dostrzec, to raczej forma folkloru. 
przyjrzenia się specyfice tożsamości wpływa na uświadomienie innym powagi omawianego zagadnienia. Bowiem ,Zbudowanie własnej tożsamości, czyli definicji samego siebie, jest niezbędne, aby jednostka zdobyła w miarę pewne przekonanie o tym, kim jest, co sobą reprezentuje i w jakim zmierza kierunku"4. Poczucie własnej tożsamości pozwala na zweryfikowanie swego pochodzenia oraz wpływa na podejmowane decyzje dotyczące przyszłości. Niezwykle ważna staje się świadomość pochodzenia, znajomość historii, korzeni, które często determinują współczesne życie jednostki. Znany polski reżyser oraz pisarz Kazimierz Kutz powiedział: „Jeśli współczesny człowiek nie będzie wiedział, skąd jest, to nie będzie wiedział, którędy w dzisiejszym świecie pójść. Świadoma tożsamość jest najtańszą busolą"5.

Pisarze sięgają po różnorakie tematy, często wykorzystując również motywy żywiołów, aby omówić istotne zagadnienia dotyczące ludzkiej egzystencji. Obok tematów pospolitych, traktujących o sprawach przyziemnych, pojawiają się często niezwykle ważne, poruszające sferę emocji i uczuć, które w zasadniczy sposób wpływają na kształtowanie się tożsamości jednostki czy grupy społecznej. Jedną z takich pozycji jest książka Siegfrieda Lenza Muzeum ziemi ojczystej, która dotyka problemów związanych z zanikającą kulturą mazurską.

Lenz chciał pokazać, w jaki sposób można próbować ochronić kulturę oraz jednocześnie tożsamość jej przedstawicieli, która odchodzi w zapomnienie, ale również wskazać, jak szybko można doprowadzić do kompletnego jej zaniku. Niewłaściwa polityka wpływa na rugowanie jakichkolwiek chęci jej podtrzymywania. Motyw ognia, który Lenz wykorzystał, pokazuje wspomnianą procedurę. Główny bohater stworzył izbę pamięci, muzeum, w którym gromadził pamiątki po dawnej kulturze mazurskiej. Pragnął zachować jej atrybuty, przekazać nowemu pokoleniu informacje o przodkach, lecz nieodpowiednie wykorzystanie zebranych materiałów

${ }^{4} \mathrm{H}$. Mamzer, Tożsamość w podróży. Wielokulturowość a kształtowanie tożsamości jednostki, WN UAM, Poznań 2002, s. 52.

${ }^{5}$ K. Kutz, Ja Ślazak, ja Polak, ja Europejczyk, „Gazeta Wyborcza”, 29 maja 2009, s. 14. 
wpłynęło na jego decyzję o zniszczeniu kolekcji. Spalił swoje muzeum, ponieważ nie zgadzał się z narzucaną ideą działania jego instytucji.

Główny bohater, Zygmunt Rogalla, od najmłodszych lat uczestniczył w procesie kolekcjonowania pamiątek mazurskich. Jako mały chłopiec został oddany do stryja Adama. W ten sposób matka Zygmunta chciała podreperować zdrowie syna, który na skutek szaleńczych eksperymentów ojca zaczął niedomagać. Chłopiec chodził z wujem po mazurskiej ziemi i swą dziecięcą łopatką wygrzebywał uwięzione w niej przedmioty. Czasem były to bezwartościowe starocie, czasem niezwykłe eksponaty. To doświadczenie z dzieciństwa stało się główną przyczyną późniejszych samozwańczych działań muzealniczych.

Lecz oto już z góry zamkowej kiwa na mnie ręką mój wuj, Adam Rogalla, niezależny etnograf, nawiedzony kret, ryjący w naszej mazurskiej przeszłości. Zaprasza mnie do grzebania w żyznym bagnie moją małą niebiesko-żółtą łopatką; uczy mnie jeśli nie zachwytu, to respektu wobec wymownych świadków naszej przeszłości, a w jego domu, który przez te lata opętańczego gromadzenia zamienił się w muzeum regionalne, dowiaduję się jeszcze raz, że wiedza o świecie zaczyna się od wiedzy o kraju albo się na niej kończy. Ponieważ umarł bezpotomnie, pewnego dnia mnie przypadły dom i muzeum. Wiele mu zawdzięczam, jemu, który zaszczepił mi ów brzemienny w skutki zapał, a w każdym razie zaszczepił tak wiele, że mógłbym od niego zacząć ${ }^{6}$.

To właśnie stryj Adam, po niespodziewanej śmierci ojca chłopca oraz bezdusznej decyzji dziadka ${ }^{7}$, przyjął pod swój dach małego Zygmunta. Chłopiec przyglądał się działaniom stryja, z czasem zaczął mu pomagać i przejmować misję kolekcjonowania eksponatów mazurskiej kultury. Po zaginięciu opiekuna młody Zygmunt kontynuował zapoczątkowane przez niego dzieło.

${ }^{6}$ S. Lenz, Muzeum ziemi ojczystej, przeł. E. Borg, M. Przybyłowska, Stowarzyszenie WK Borussia, Olsztyn 2010, s. 12-13.

${ }^{7}$ Ojciec, Jan Rogalla, był bratem Adama, a dziadek ojcem ojca. Dziadek wyrzucił młodego Zygmunta i matkę z dzierżawionego majątku. Kobietę z dzieckiem przyjął brat męża - Adam. 
Bohater nie poddał się zawirowaniom dwóch wojen, mimo że odcisnęły one swoje piętno na wszystkich aspektach ludzkiego istnienia; szczególnie druga wojna światowa, w czasie której próbowano narzucić nazistowską ideologię. To wtedy zakiełkowały w Rogalli wątpliwości co do „czystości” historii. Dostrzegł on, że historią można manipulować, „naginać” do swych teorii, dostosowywać wykładnię do panujących warunków. Jeden z bohaterów, Bilitza, twierdził:

Co z tego za pożytek, gdy gromadzi się znalezisko po znalezisku - rzeczy zyskują swoje właściwe znaczenie dopiero dzięki organizacji, to znaczy gdy zaczynają służyć jakiejś myśli, jakiejś wielkiej idei. Każdy wie, że nasi przodkowie pracowali i walczyli, że pielęgnowali swoje obyczaje; dowodzenie tego jest niemal zbyteczne; chodzi o to, by znalezisko mogło posłużyć jako dowód, że Mazurzy czuli się zawsze forpocztą niemczyzny na Wschodzie. Znaleziska te nie mogą jedynie o czymś świadczyć, muszą też coś demonstrować, muszą agitować ${ }^{8}$.

Dygnitarze Rzeszy próbowali wpłynąć na interpretację zbiorów Rogalli. Jego eksponaty miały wyjaśniać ideologię, tłumaczyć ich postępowanie. Historia zaklęta $\mathrm{w}$ eksponatach miała zostać dopasowana do aktualnej sytuacji, potwierdzać wyznawane zasady, utwierdzać w światopoglądzie.

Zygmunt nie uległ podobnym namowom. Stale gromadził mazurskie artefakty, poszerzał swoją kolekcję. Aby nie poddać się naciskom dygnitarzy, zmienił organizację swej izby. Przed wybuchem wojny udostępniał muzeum zwiedzającym, pobierając opłaty. Aby zrzucić płaszcz państwowego charakteru placówki, zrezygnował z biletów. Tym samym muzeum stało się zbiorem prywatnym, a państwo utraciło możliwości ingerencji w jego zbiory. Bohater zdobył szansę na własny dobór eksponatów - kolekcjonował już według własnych przekonań, bez konieczności dopasowania się do wytycznych państwa.

Niestety izba pamięci nie przetrwała. Zawirowania wojny zmusiły Zygmunta do ucieczki. W tak trudnym momencie samozwańczy

\footnotetext{
${ }^{8}$ S. Lenz, Muzeum ziemi ojczystej, s. 326.
} 
etnograf nie zapomniał o kolekcji, której część zabrał, przewożąc ją w niebezpiecznych warunkach wozem drabiniastym, potem statkiem do Egenlund. Tam zaczął odbudowywać swoje dzieło zapoczątkowane w Łukowcu. Ponownie stworzył izbę pamięci z pamiątek przywiezionych z Mazur, jak również z podarowanych mu przez ludzi eksponatów. Kontynuował dzieło aż do momentu odwiedzin polskich reporterów, którzy chcieli nakręcić film dokumentalny o placówce Rogalli. Ich wizyta przyczyniła się do kłótni pomiędzy trzema dawnymi mieszkańcami Łukowca: Zygmuntem, jego przyjacielem Connym oraz Przytullą. O ile Rogalla trwał w przekonaniu o „czystości” historycznej, o tyle pozostali chcieli dopasować zbiór eksponatów do panujących warunków:

Wciąż jeszcze brałem ich żądania za efekt złego humoru, a na moje pytanie, czy Conny życzy sobie nieskazitelnej historii Łukowca, takiej, która by nikogo nie obciążała, odpowiedział z początku tylko wzruszeniem ramion, ale zaraz potem musiałem przyjąć do wiadomości, że nie poprzestali na pojedynczym, mniej lub bardziej przypadkowym zarzucie. Ich rozgoryczenie, ich rozczarowanie samymi sobą kazało im teraz nieprzerwanie gorszyć się; to, co jeszcze ostatnim razem oglądali z zachwytem albo wzruszeniem, nagle wydawało im się fatalne, niesmaczne, wręcz obciążające - mogłeś się tylko zdumiewać, dlaczego dostrzegli to dopiero teraz. Conny przeczytał szyldzik pod ozdobną faską na masło, pochodzącą z wielkiego łuku Wisły, i stwierdził, że teraz rozumie już powód, dlaczego kamerzysta poświęcił mu przesadnie dużo uwagi; a po lekturze paru innych tabliczek oświadczył, iż otworzyły mu się oczy na to, dlaczego bladoniebieską narożną szafę, zębaty wałek do międlenia lnu czy skromne krzesło chłopskie fotografowano z jak najbliższej odległości - dotarły one niegdyś do Łukowca $z$ tamtej strony granicy ${ }^{9}$.

Według nich zbiór eksponatów powinien być historycznie jednorodny, bez możliwości dzielenia się z innymi kulturami. Miała to być prosta, jednoliniowa historia Mazur. Zapewne nie byli oni świadomi, że

\footnotetext{
${ }^{9}$ Tamże, s. 572.
} 
Mazury tamtych czasów to teren typowego pogranicza kulturowego ${ }^{10}$. Według Antoniny Kłoskowskiej pogranicze to

terytorium położone między dwoma obszarami państwowymi lub regionalnymi, charakteryzujące się przemieszaniem etnicznym lub narodowościowym wynikającym z bliskości przestrzennej. W szerszym, przyjętym tu rozumieniu pogranicze stanowi wielkie sąsiedztwo kultur narodowych mogące wynikać z narodowo i etnicznie mieszanej genealogii i małżeństwa, z członkostwa w mniejszości narodowej lub etnicznej na terytorium zdominowanym przez inną narodową kulturę, z sytuacji emigracyjnej oraz $\mathrm{z}$ indywidualnej konwersji narodowej, czyli przejścia od jednego do innego narodowego samookreślenia, które nie może oznaczać całkowitego zerwania poprzednich więzi kulturowych ${ }^{11}$.

Przyglądając się regionowi kreślonemu przez Lenza, łatwo zauważyć, że miejsce to spełnia większość wyznaczników pogranicza kulturowego. Funkcjonujące ze sobą różne kultury, wielorakie relacje, zarówno te pozytywne, jak i negatywne, czy charakterystyczna relacja swójobcy, wskazują, że ówczesny mazurski region można uznać za teren pogranicza kulturowego.

Conny i Przytulla, tkwiąc w swej „tutejszości”, nie byli w stanie dostrzec efektów wielostronnego wpływu różnych kultur. Postrzegali swoje Mazury jako miejsce, gdzie trzeba nauczyć się specyficznej egzystencji, dopasowując się do trudnej przyrody i klimatu. Łatwiej było im zrozumieć przyrodę niż sąsiada, który wyznawał inne poglądy. A to właśnie ludzie (mieszkańcy), ich wytwory i światopogląd tworzą specyfikę danego obszaru. To oni określają miejsca oswojone i miejsca obce, wyznaczają swych przyjaciół i wrogów, tworzą i interpretują historię. W swym działaniu mają wybór, mogą przekazywać historię prawdziwą,

${ }^{10}$ Wielokulturowy świat Siegrieda Lenza. Studia, red. J. Ławski, R. Żytyniec, Uniwersytet w Białymstoku, Białystok-Ełk 2014; J. Zaprucki, Kultury reminiscencji - reminiscencje kultury. Motyw małej ojczyzny w twórczości Siegfrieda Lenza, Horsta Bienka i Johannesa Bobrowskiego, Kolegium Karkonoskie Państwowej Wyższej Szkoły Zawodowejwydawca. Jelenia Góra 2006.

${ }^{11}$ A. Kłoskowska, Kultury narodowe u korzeni, WN PWN, Warszawa 1996, s. 125. 
z jej różnymi zawiłościami, mogą również „naginać” ją do swych ideologii.

Postawa Conny'ego oraz Przytulli wskazuje na próbę dopasowania historii do obowiązującej sytuacji. Bohaterowie wychodzili z założenia, że należy zniwelować możliwości różnych interpretacji historii Mazur w powiązaniu z innymi kulturami ościennymi. Historia ich Heimatu miała być jednostronna, jasna i prosta. Nie było tam miejsca na jakiekolwiek wpływy czy naleciałości. Nie mieli świadomości, lub nie chcieli zaakceptować faktu, że Mazury to specyficzny tygiel kulturowy, gdzie wzajemne relacje wpisane są w egzystencję ich mieszkańców.

To właśnie wtedy zakiełkowała w Rogalii myśl zniszczenia zbiorów. Zygmunt nie chciał dopuścić do sytuacji, by jego muzeum było wykorzystywane do jakichkolwiek celów politycznych czy ideologicznych. Wyznawał zasadę, że historię należy przekazywać bez retuszu. Należy pokazywać jej wszystkie dobre i złe strony - zawirowania, relacje oraz wszelkie wpływy. Tylko wtedy jest ona autentyczna i bez fałszu obrazuje dzieje danej grupy społecznej. Spalenie muzeum uniemożliwiało kontynuację procesu zmieniania i dopasowania wydarzeń, jak również doboru eksponatów do aktualnych sytuacji dziejowych.

Zygmunt Rogalla, przyznaje się do podpalenia muzeum, które sam wcześniej tak mozolnie tworzył.

To ja podłożyłem ogień pewnego wieczoru osiemnastego sierpnia, nie pozostało mi nic innego, jak tylko zniszczyć jedyne muzeum ziemi mazurskiej tam na zachodzie, w Egenlund koło Szlezwiku. To nie był przypadek, mój drogi. Tak jak niegdyś budowa i urządzenie muzeum było moim własnym pomysłem, tak i teraz wyłącznie ja zdecydowałem o jego całkowitym zniszczeniu, razem ze wszystkimi świadectwami i dokumentami, które się w nim znajdowały, a które wraz z przyjaciółmi zgromadziłem tu po wojnie ${ }^{12}$.

Bohater nie tylko podpalił muzeum, ale wręcz nie pozwolił gasić pożaru.

\footnotetext{
${ }^{12}$ S. Lenz, Muzeum ziemi ojczystej, s. 5.
} 
Tak, słusznie pan przypuszcza: nawet jeśli nikt nie ważył się w mojej obecności gasić pożaru, to przecież nie brakowało prób ratowania w ostatniej sekundzie niektórych eksponatów, zagrożonych przez ogień; córka prosiła mnie, bym pozwolił wynieść w bezpieczne miejsce chociaż spis słownictwa mazurskiego, zbiór, do którego powstania się przyczyniła, pilnie kaligrafując. Odmówiłem.... Henrike panu o tym opowiadała? No dobrze.... Nie dałem ratować starej, ozdobnej beczułki do masła, która tyle znaczyła dla żony, zabroniłem też Marianowi wyciągnąć z ognia mój błękitno-biały ślubny kilim... ${ }^{13}$.

Wszystkie eksponaty miały spłonąć, namacalne dowody istnienia dawnej kultury mazurskiej miały się stać przebrzmiałą historią. Według założeń Rogalli nie mogły one zostać wykorzystane do manipulowania historią.

Sytuacja zmieniła się, gdy pożar przeniósł się na dom mieszkalny. Bohater rzucił się wtedy do ratowania dobytku.

Myli się pan. Gdy pożar przerzucił się na dom mieszkalny, ja pierwszy podjąłem środki zaradcze, by nie dopuścić do rozprzestrzeniania się ognia. Utworzyliśmy łańcuch, podając sobie wiadra z rąk do rąk. Podzieliliśmy się, stając w sieni, na schodach, na piętrze nad tkalnią, wiadra wędrowały od kranu, gdzie stała moja żona, aż do Simona Gayko, który podawał je do mnie na górę przez właz w dachu; początkowo wyglądało na to, że woda, którą rozlewałem po dachu, zdoła zatrzymać ogień, ale to dym, właśnie dym zmusił do opuszczenia włazu. [...] Ponieważ nie pozostało nam nic innego do zrobienia, próbowaliśmy w pojedynkę lub pospołu ratować wartościowe przedmioty i wynosić na dwór wszystko, co się dało, przede wszystkim pościel, meble i odzież, a nawet rozpoczęte prace naszych uczennic. Pracowaliśmy, dopóki pozwalały na to żar i dym. Tylko córka odmówiła w tym udziału ${ }^{14}$.

Ponieważ dom nie był miejscem bezpośrednio związany z muzeum, bohater nie chciał dopuścić do jego spalenia. Stąd jego determinacja w próbie ratowania dobytku.

\footnotetext{
${ }^{13}$ Tamże, s. 7.

${ }^{14}$ Tamże, s. 8.
} 
Niewątpliwie ogień jest żywiołem, który pochłania wszystko, co napotka na swej drodze. Może mieć jednak również swoiste funkcje budujące. Nie są to realne budowle, lecz tworzenie pewnych konstrukcji myślowych, zmian mentalnych. Poprzez realne spalenie konkretnego przedmiotu może dojść do samooczyszczenia oraz wyciszenia emocji. Jest to dobra baza do budowania czegoś nowego - nie tylko przedmiotów czy obiektów, ale również do krystalizowania nowych poglądów, uczenia się nowych emocji.

Bohater powieści Lenza jest świadomy, że aby uporządkować jedne sprawy, musi dojść do unicestwienia poprzednich. Musi nastąpić swoiste oczyszczenie.

Co pan mówi? Że zbyt wiele uległo zniszczeniu? Rzeczy nie do odtworzenia? Przykro panu na myśl o stratach? Kto chce uporządkować swoje sprawy, drogi Martinie, ten musi liczyć się z bólem, a mnie nie pozostało nic innego, jak tylko zaprowadzić ład w swoich sprawach, po wszystkim, co zaszło, tak po wszystkim ${ }^{15}$.

W spaleniu muzeum bohater dostrzega możliwość zbudowania czegoś nowego, nowej jakości, nowej idei. Rozumie, że wiąże się to $\mathrm{z}$ ogromną stratą (materialną i duchową), z bólem. Pomimo wielu zniszczeń, podobne sytuacje uważa bohater za zapowiedź nadchodzących zmian, które pomogą $\mathrm{w}$ konstruowaniu nowych autentycznych historii.

Spalone eksponaty muzeum Rogalli miały pozostać w innej sferze, w sferze duchowej, umysłowej. Maria Popczyk stwierdza:

(Bachelard zauważa, że) ogień jest jednym z żywiołów, którego ruch cechuje przyspieszone tempo będące nieprzepartą siłą sprowadzenia wszystkiego do kresu. [...] Taki ogień odzwierciedla ludzki czyn, który rządzi się logiką zagłady, w tym wypadku niszczenie ma nadzieję czerpać energię, do nowego życia, $\mathrm{z}$ narodzin początku ${ }^{16}$.

${ }^{15}$ Tamże, s. 10.

${ }^{16}$ M. Popczyk, Ogień, Ogień, w: Estetyka czterech żywiołów. Ziemia. Woda. Ogień. Powietrze, red. K. Wilkoszewska, Universitas, Kraków 2002, s. 159. 
Podpalenie muzeum było czynem skazującym obiekt na realne unicestwienie. Miało jednocześnie ukryty, zawoalowany cel, jakim była szansa przekazania historii bez upiększeń i odwzorowań.

W zakończeniu książki czytelnik poznaje pobudki głównego bohatera, dowiaduje się, dlaczego podpalił on dzieło swego życia, czym kierował się przy podejmowaniu tak trudnej decyzji.

Znosząc farbowane resztki wełny, taszcząc tu i tam kanister z benzyną, którego zawartość miała nasączyć przędzę, zanim w końcu schowałem go pod strojami, wybierając już miejsca, gdzie miały wybuchnąć pierwsze płomienie, i odpierając tysiące pokus, by to czy tamto w ostatniej chwili przemycić na bok, miałem tylko jedno pragnienie - przenieść wszystkich świadków naszej przeszłości w bezpieczne miejsce, zapewnić im ostateczne, nieodwołalne bezpieczeństwo, skąd wprawdzie nigdy więcej się nie ukażą, ale też gdzie nikt już nie będzie mógł nimi zawładnąć, by przemówiły dla niego ${ }^{17}$.

Główny bohater doszedł do wniosku, że nie można wykorzystywać świadków przeszłości dla osobistych pobudek innych osób, mających odmienne wyobrażenie o misji jego muzeum. Miał świadomość, że współczesny człowiek wykorzystuje historię do pokazania swojego punktu widzenia. Nie zgadzał się na nadinterpretację oraz „naginanie” faktów w celu osiągnięcia osobistych celów. Z tego powodu zdecydował się na zniszczenie dowodów i przeniesienie potencjalnych świadków w stan wspomnień, do pamięci. Tym samym świadkowie minionych czasów mieli być bezpieczni i nienarażeni na nieodpowiednie przywoływanie.

W tym miejscu można pokusić się o stwierdzenie, że główny bohater zmienił wektor pamięci - z pamięci intersubiektywnej zbiorowości/społeczności do subiektywnej jednostki. Wszystkie dotychczasowe informacje przekazywane w namacalnej formie dostępne były szerszemu gronu. Po spaleniu artefaktów (kolekcji) informacje te pozostaną w świadomości konkretnej jednostki, która podejmie trud ich podtrzy-

\footnotetext{
${ }^{17}$ S. Lenz, Muzeum ziemi ojczystej, s. 580-581.
} 
mywania. Jeśli jednostka nie przekaże ich następnym pokoleniom, istnieje zagrożenie zaniku danej kultury. Ustne przekazywanie elementów kultury wiąże się również z pewnym uproszczeniem lub wręcz zakłamaniem. Człowiek przekazuje informacje tak, jak je zapamiętał. A każdy taki akt pamięci to pewna interpretacja. Czasem nadinterpretacja.

Książkę kończy dosyć gorzka konkluzja: „Strzeżone znaleziska rozsypały się, ślady zostały zatarte. Przeszłość odzyskała to, co do niej należy, a co nam tylko na krótko wypożyczyła. Ale pamięć już znowu się budzi, już szuka i zbiera wspomnienia w niepewnej ciszy ziemi niczyjej"18. Pewną dozą optymizmu są słowa mówiące o pamięci, która zawsze funkcjonuje w każdym społeczeństwie, zarówno w pamięci indywidualnej, jak i zbiorowej. Pamięć należy do tych kategorii, które konstruują obecną rzeczywistość, bazując na rzeczywistości minionej, wpływając równocześnie na kształtowanie własnej tożsamości. Warto jednak pamiętać, że pamięć może być zwodnicza i zatrzymywać tylko określone elementy. Główny bohater książki czeskiego pisarza Oty Filipa stwierdza: „ale sami dobrze wiecie, że pamięć ludzka jest tak zorganizowana, że układa wspomnienia nie tyle chronologicznie, ale w zależności od tego jak mocno przeżyliśmy to czy owo wydarzenie"19. To właśnie te najbardziej emocjonalne przeżycia zostają zapamiętane. Takie zatrzymane wydarzenia zazwyczaj nie układają się w chronologiczną całość, lecz występują punktowo, wraz z natężeniem konkretnych uczuć i emocji. Lojzek Lapaczek stwierdza dalej, że „,[w]szyscy zostawili we mnie ślady. Tkwią i wciąż zmuszają do myślenia"20. Bowiem niezaprzeczalnie to ludzie i ich działania kształtują ówczesną rzeczywistość, która wpływa na kształt ogólnego postrzegania siebie oraz otaczającego świata.

Tożsamość jest zagadnieniem wieloaspektowym, wielowarstwowym, które wymaga wielorakich spojrzeń. W obszarze tym swoiste

${ }^{18}$ Tamże, s. 581 .

${ }^{19}$ O. Filip, Wniebowstapienie Lojzka Lapaczka ze Ślaskiej Ostrawy, przeł. J. Stachowski, Świat Książki, Warszawa 2005, s. 364.

${ }^{20}$ Tamże, s. 553. 
miejsce zajmują kultury regionalne, etniczne, często balansujące na styku przetrwania. To, co przedstawiciele danej kultury, jak również osoby decyzyjne, uczynią z jej pozostałościami wpłynie na jej dalszy stan - funkcjonowanie lub zanik. Podtrzymywanie tożsamości lokalnej, regionalnej czy etnicznej ma ogromny wpływ na zrozumienie siebie oraz zmian w otaczającym świecie zachodzących na przestrzeni lat. Warto zaznaczyć, że

[t]ożsamość jest projektem refleksyjnym, za który jednostka jest odpowiedzialna. [....] Jesteśmy nie tym, czym jesteśmy, ale tym, co z siebie zrobimy. $[\ldots]$ to, kim stanie się jednostka, wynika $\mathrm{z}$ jej starań zmierzających do jej rekonstrukcji. [...] Samorozumienie jest podporządkowane szerszemu i bardziej fundamentalnemu celowi, jakim jest wytwarzanie i odtwarzanie spójnego i satysfakcjonującego poczucia tożsamości ${ }^{21}$.

To od jednostki, tworzącej daną społeczność lokalną, regionalną, etniczną, zależy jaki kształt i wygląd przybierze jego mała ojczyzna, a tym samym jak będzie kształtowała się jego tożsamość.

\section{Bibliografia}

Bokszański Z., Tożsamości zbiorowe, WN PWN, Warszawa 2015.

Filip O., Wniebowstapienie Lojzka Lapaczka ze Ślaskiej Ostrawy, przeł. J. Stachowski, Świat Książki, Warszawa 2005.

Giddens A., Nowoczesność i tożsamość. „Ja” i społeczeństwo w epoce późnej nowoczesności, tt. A. Szulżycka, WN PWN, Warszawa 2010.

Kłoskowska A., Kultury narodowe u korzeni, WN PWN, Warszawa 1996.

Kutz K., Ja Ślazak, ja Polak, ja Europejczyk, „Gazeta Wyborcza” 29 maja 2009.

Lenz S., Muzeum ziemi ojczystej, przeł. E. Borg, M. Przybyłowska, Stowarzyszenie WK Borussia, Olsztyn 2010.

Mamzer H., Tożsamość w podróży. Wielokulturowość a ksztattowanie tożsamości jednostki, WN UAM, Poznań 2002.

Popczyk M., Ogień, w: Estetyka czterech żywiołów. Ziemia. Woda. Ogień. Powietrze, red. K. Wilkoszewska, Universitas, Kraków 2002.

${ }^{21}$ A. Giddens, Nowoczesność i tożsamość. „Ja” i spoleczeństwo w epoce późnej nowoczesności, przeł. A. Szulżycka, WN PWN, Warszawa 2010, s. 12. 
Justyna Szlachta-Ignatowicz, Muzeum ziemi ojczystej (Heimatmuseum). . 375

Skarga B., Tożsamość i różnica. Eseje metafizyczne, Znak, Kraków 1997.

Wielokulturowy świat Siegrieda Lenza. Studia, red. J. Ławski, R. Żytyniec, Uniwersytet w Białymstoku, Białystok-Ełk 2014.

Zaprucki J., Kultury reminiscencji - reminiscencje kultury. Motyw małej ojczyzny w twórczości Siegfrieda Lenza, Horsta Bienka i Johannesa Bobrowskiego, Jelenia Góra 2006.

\section{Siegfried Lenz's "Museum of the native land" (Heimatmuseum) as a story of an attempt to save}

Identity issues can be considered from many perspectives. One of the many ways is to try to describe the culture of a small community that is slowly disappearing due to historical turmoil. Siegfried Lenz's book "Museum of the native land" addresses such topics. The book touches on problems related to the disappearing Masurian culture. Lenz wanted to show how you can try to protect the culture and the identity of its representatives that is falling into oblivion, but also to show how quickly it can be brought to a complete disappearance. Arson by the main character of the museum he created is to serve as a symbol of opposition to manipulation of history, bending it to his theories and adapting the interpretation to prevailing conditions. Rogalla wants to preserve historical purity, and treats the confused fate of the Masurian land as an indicator of its culture and the identity of its inhabitants.

Keywords: identity, fire, Masuria, museum, borderland, memory 
